\title{
ADAPTIVE HOMESTAY SEBAGAI BENTUK PARTISIPASI MASYARAKAT UNTUK MELESTARIKAN DESA WISATA PENTINGSARI - YOGYAKARTA
}

\author{
Vincentia Reni Vitasurya \\ Program Studi Arsitektur, Fakultas Teknik, Universitas Atma Jaya Yogyakarta, \\ Jalan Babarsari no 44, Yogyakarta, Indonesia \\ Email: reni792003@yahoo.com atau renivs@mail.uajy.ac.id
}

\begin{abstract}
Abstrak
Perkembangan pariwisata di daerah tujuan wisata terkait erat dengan pengembangan sektor ekonomi di wilayah atau negara. Pengembangan pariwisata diharapkan dapat mendatangkan manfaat bagi masyarakat. Yogyakarta sebagai salah satu tujuan wisata telah mengembangkan berbagai alternatif yang dapat ditawarkan kepada wisatawan. Desa wisata Pentingsari adalah salah satu desa wisata andalan di Yogyakarta. Desa telah terbukti berjalan dengan baik dan dipelihara kelestariannya sejak 2008. Pelestarian desa ini dimungkinkan melalui partisipasi masyarakat untuk berpartisipasi dan terlibat dalam kegiatan pariwisata desa. Salah satu yang mendukung keberhasilan kegiatan ekowisata adalah homestay. Terkait dengan industri pariwisata, homestay dapat dipahami sebagai dua hal: sebagai obyek wisata dan sebagai akomodasi wisata. Desa Pentingsari memiliki homestay permanen milik warga yang sudah berjalan dengan baik. Penelitian ini bertujuan melihat relevansi rumah warga yang menjadi homestay sebagai bentuk partisipasi warga dalam industri pariwisata pedesaan, namun tetap menjaga kelestarian alam dan lingkungan. Metode yang digunakan adalah metode partisipasi riset aksi dengan observasi lapangan, wawancara mendalam serta penelusuran sejarah. Hal ini untuk menemukan seberapa besar peran warga untuk menjaga kelestarian lingkungan sebelum dan sesudah menjadi desa wisata. Hasil penelitian ini menunjukkan model pengembangan desa wisata
\end{abstract}

Kata kunci: homestay, ekowisata, desa wisata, pariwisata, partisipasi masyarakat

\section{Abstract \\ Title: Adaptive Homestay as a Form of Community Participation to Preserve Pentingsari Tourist Village, Yogyakarta}

The development of tourism in a tourist destination is linked to the development of economic sectors in the region or the country. The development of tourism is expected to bring benefits to the community. Yogyakarta as one of the tourist destinations has developed a range of alternatives that can be offered to travelers. Pentingsari tourist village is one of the mainstay tourism village in Yogyakarta. The village has been proven to run well and maintained its continuity since 2008. Preservation of the village was made possible through the participation of citizens to participate and engage in their village tourism activities. One that supports the success of ecotourism activities is homestay. In relation to the tourism industry, homestay can be described as two things: as a tourist attraction and as a tourist accommodation. Pentingsari village already has homestays which are village houses that already run well. This research seeks homestay relevance as a form of citizen participation in the rural tourism industry while maintaining the conservation of the environment. The methods used is participatory research action by field observation, in depth interviews and historical documents tracing. This is to determine how much the role of citizens to preserve the environment before and after becoming a tourist village. These results indicate a model of rural tourism development

Keywords: Home stay, ecotourism, tourism village, tourism, community participation 


\section{Pendahuluan}

Ekowisata dan wisata minat khusus merupakan "trend" baru yang perlu dicermati perkembangannya (Fandeli, 2000). Yogyakarta yang menyandang kota pariwisata juga tidak luput dari pengaruh "trend" ini. Bentuk aktivitas pariwisata berbasis ekowisata dan atau budaya mulai bermunculan di Daerah Istimewa Yogyakarta, terutama di sekitar Kabupaten Sleman dan Bantul. Tahun 2012 jumlahnya mencapai 38 desa wisata (Dinas Kebudayaan dan Pariwisata, Kabupaten Sleman, 2012). Dari data tersebut terlihat pertumbuhan minat masyarakat untuk menikmati jenis pariwisata model baru ini. Minat pemerintah untuk mendorong pengembangan desa wisata dapat terlihat dari diadakannya berbagai lomba dan penghargaan desa wisata. Perkembangan desa berbasis agraris menjadi desa wisata merupakan fenomena menarik yang perlu diteliti secara berkelanjutan untuk melihat kearifan lokal yang dapat mensejahterakan masyarakat pedesaan.

Pariwisata berkelanjutan di pedesaan memiliki makna mengembangkan kawasan pedesaan menjadi desa wisata yang berbasis pada kelestarian lingkungan alamiah yang mengandalkan gaya hidup agraris sebagai salah satu atraksi wisatanya, namun memiliki nilai ekonomis yang lebih besar dari sebelumnya. Hal ini sejalan dengan tuntutan perdesaan ${ }^{1}$ sebagai tujuan wisata (Royo-Vela, 2009) yang melihat makna wisata pedesaan sebagai tujuan wisata melalui lima fokus yang berbeda, yaitu daur hidup, nilai kontingen, pengalaman wisata, kualitas tujuan, dan citra tujuan (lifecycle, contingent value, tourist

${ }^{1}$ Menurut Kamus Besar Bahasa Indonesia, perdesaan adalah kumpulan pedesaan. experience, destination quality, and destination image). Artinya, wisata perdesaan sangat terkait dengan 1) obyek kehidupan keseharian di pedesaan yang khas, 2) nilai-nilai khas perdesaan yang menarik untuk dipelajari, 3) bentuk pengalaman berwisata yang berbeda dengan tujuan wisata yang lain, 4) kualitas wisata yang lebih banyak memuat unsur pendidikan, 5) citra perdesaan sendiri yang terkait dengan keindahan tempat dan budaya khas dan citra tempat yang damai, bersih, dan penuh keramahtamahan (Tim Puswira, 2011, 2012).

Seiring dengan peningkatan ekonomi masyarakat, maka akan diikuti pula dengan bentuk modernisasi yang beragam seperti luas lingkungan terbangun, jumlah kamar yang digunakan sebagai ruang inap (homestay) meningkat, maupun kualitas ruang dari sisi bentuk, tatanan, dan makna ruangpun akan berubah sesuai dengan persepsi masyarakat akan bentuk kemajuan tersebut. Persepsi wisatawan yang berminat berwisata di pedesaan mungkin berbeda dengan persepsi masyarakat tersebut. Seperti yang terjadi di Desa Pentingsari, Sleman Yogyakarta, justru budaya asli yang ada di desa menjadi daya tarik utama (Pudianti, 2013), sedangkan masyarakat, dengan inisiatifnya sendiri melalui kelompok sadar wisata (Pokdarwis) mengubah desanya sesuai dengan persepsi mereka sendiri.

Jadi jelaslah bahwa faktor manusia (masyarakat pedesaan) perlu lebih diberdayakan agar dapat terus melestarikan lingkungannya sehingga tetap memiliki daya tarik khas pedesaan, namun maju secara perekonomian (Purwaningsih et.al, 2014). 
Lokasi penelitian ini mengambil tempat di desa wisata Pentingsari yang berada di kabupaten Sleman Propinsi Daerah Istimewa Yogyakarta. Posisinya dapat dilihat pada gambar 1 .

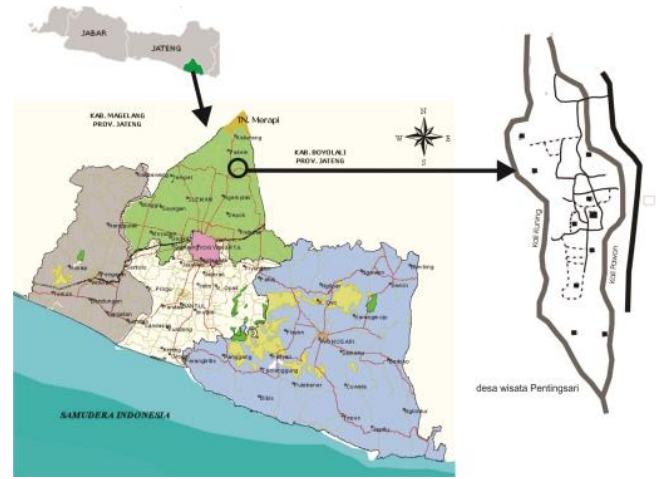

Gambar 1. Lokasi desa wisata Pentingsari Yogyakarta.

Sumber: Hasil survei, 2014

Pada contoh desa Pentingsari terlihat adanya kekuatan di desa tersebut yang menyebabkan masyarakat dapat terus menarik minat wisatawan untuk berkunjung dan sekaligus tetap melestarikan kehidupan agrarisnya. Bahkan, konsep pelestarian lingkungan di desa ini sangat terlihat dengan penghargaan yang diterimanya sebagai juara I lomba antar desa wisata tingkat Nasional untuk kategori "Alam yang Unik dan Pelestarian Budaya" pada tahun 2009 , dan juga penghargaan dari PBB untuk kategori "Pelestarian Alam dan Budaya" pada tahun 2011. Secara umum, daya tarik wisata di desa Pentingsari mengakibatkan peningkatan kunjungan wisata yang datang dari tahun ke tahun. Hal ini dapat dilihat pada tabel berikut :

Tabel 1. Kunjungan wisatawan di Desa Wisata Pentingsari, Sleman

\begin{tabular}{ccc} 
Tahun & Jumlah & Kenaikan \\
\hline 2008 & 1.293 & \\
2009 & 5.008 & $287 \%$ \\
2010 & 9.576 & $91 \%$ \\
2011 & 13.156 & $37 \%$ \\
2012 & 20.479 & $56 \%$ \\
\hline
\end{tabular}

Sumber: Pudianti, 2013

\section{Metode}

Metode Partisipasi Riset Aksi (Participatory Action Research-PRA) akan diterapkan dalam penyelesaian persoalan yang muncul dalam penelitian ini. Metode penelitian dirinci dan diuraikan sesuai dengan keperluan. Metode penelitian dilengkapi dengan bagan penelitian yang dibuat secara utuh dengan penahapan yang jelas, teknik-teknik pengumpulan data yang tidak umum perlu dijelaskan, demikian pula analisis yang dilakukan, luaran per tahun, dan indikator capaian yang terukur.

Jenis penelitian ini menekankan pelibatan sasaran sebagai subyek yang aktif, menjadikan pengalaman mereka sebagai bagian integral dalam penelitian, menemukan permasalahannya, dan semuanya diarahkan untuk pemecahan persoalan sasaran dalam konteks pemberdayaan subyek penelitian. Kegiatan penelitian dan aksi menjadi satu kesatuan kegiatan yang berjalan berkesinambungan dan saling mengisi untuk menemukan pemecahan masalah atas subyek yang diteliti. Oleh karena itu, metode partisisipatif riset aksi diidentikkan dengan riset pemberdayaan (Mikkelsen, 2001). Untuk mencapai tujuan penelitian, maka metode partisipatif riset aksi yang dipakai sebagai fokus perlu didukung oleh metode lainnya seperti: observasi, indepth interview, focus group discussion (FGD). Secara skematik, alur pola pikir pembahasan pada tulisan ini digambarkan pada skema berikut: 


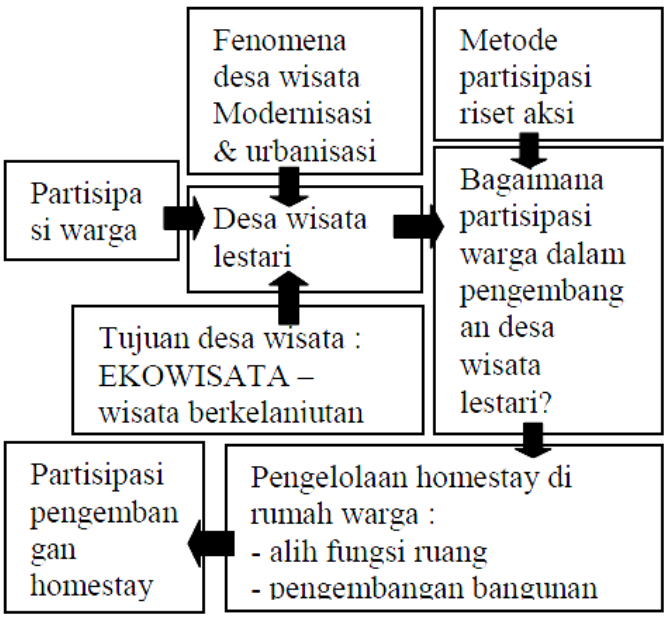

Gambar 2. Skematik pola pikir

Sumber: Hasil analisis, 2015

\section{Gambaran Lokasi}

\section{Potensi desa wisata Pentingsari}

Desa wisata Pentingsari memiliki beberapa potensi alam sebagai atraksi wisata yang dapat menjadi daya tarik wisata setempat. Sebaran atraksi wisata tersebut dapat dilihat pada gambar 3 berikut ini.

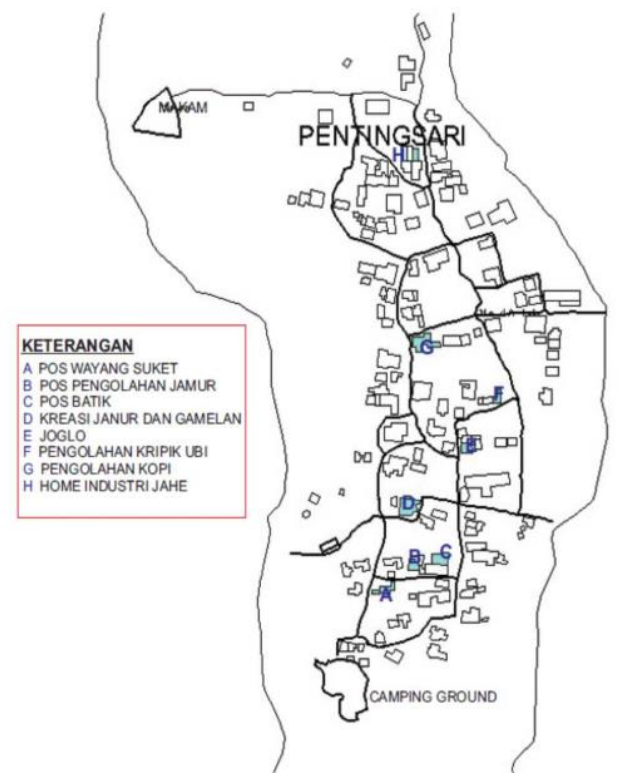

Gambar 3. Sebaran potensi atraksi wisata desa Pentingsari.

Sumber: Hasil survei, 2014

Atraksi yang menjadi andalan wisata di desa Pentingsari adalah :
1. Homestay, penginapan tradisional di rumah - rumah penduduk desa.

2. Treking jalur lintas alam, menanfaatkan potensi alam pegunungan di lereng gunung Merapi.

3. Camping, tersedia lahan luas sebagai area camping.

4. Outbond, tersedia lahan luas yang sudah dimodifikasi sebagai sarana outbond

5. Workshop pertanian, perikanan dan peternakan menggunakan lahan milik warga desa.

6. Workshop Kerajinan tradisional seperti wayang rumput, menjanur dan membatik.
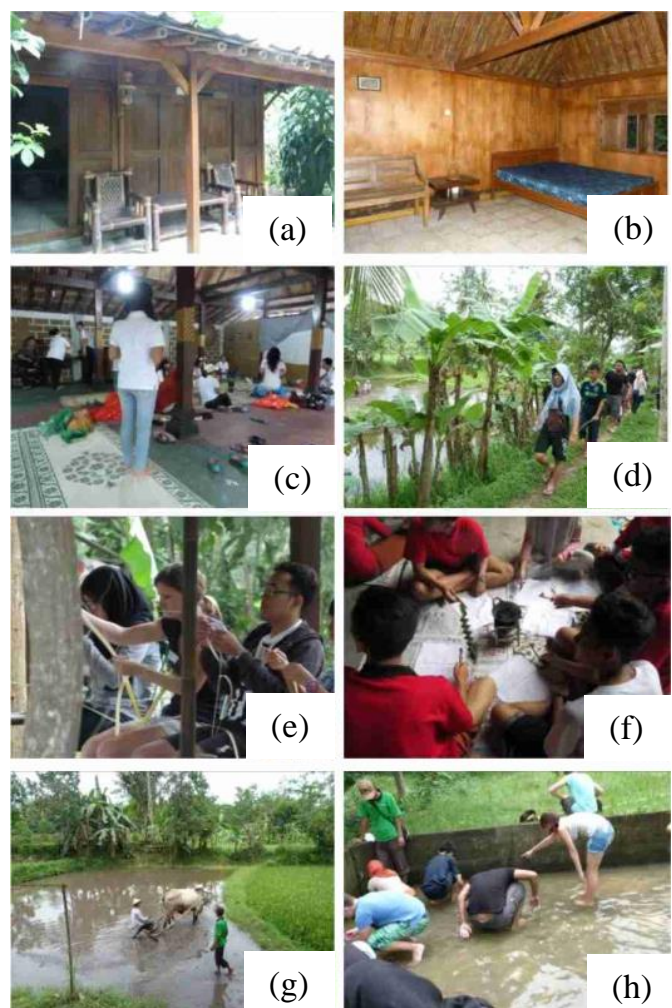

Gambar 4. Dokumentasi atraksi wisata di desa Pentingsari (a) dan (b) Fasilitas homestay (c) aktivitas membatik (d)aktivitas trekking (e) dan (f) aktivitas menjanur (g) dan (h) aktivitas pertanian.

Sumber: Hasil survei, 2014

Gambaran aktivitas wisata dapat dilihat pada dokumentasi gambar 4. Hal ini sekaligus menunjukkan tingginya 
minat wisatawan untuk berwisata di desa tersebut.

\section{Pengembangan homestay}

Desa Pentingsari, hingga tahun 2014 telah mengalami peningkatan secara ekonomi. Bapak Tony Siswoyo selaku tokoh masyarakat setempat menjelaskan bahwa setelah menjadi desa wisata, perekonomian warga yang dulunya terseok-seok sekarang sudah lebih baik, dan itu sudah bisa dirasakan masyarakat secara langsung. dengan adanya desa wisata semua masyarakat memiliki peran masing-masing, yaitu menyewakan homestay (83\%), pemandu wisata $(25,5 \%)$, pemandu acara kesenian $(12,8 \%)$, industri makanan (17\%), industri kerajinan $(6,4 \%)$, katering $(16,1 \%)$. Minimal masyarakat dilibatkan untuk dapat menyewakan rumahnya sebagai homestay bagi para wisatawan. (Herawati et al, 2014)

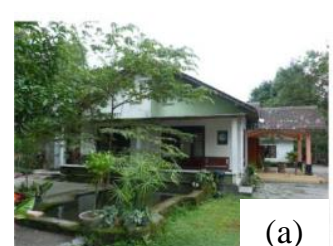

(a)

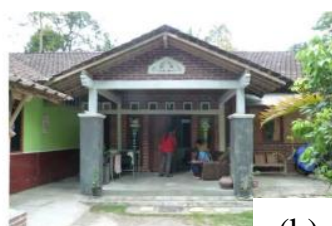

(b)
Gambar 5. Homestay rumah warga desa Pentingsari (a) rumah ibu Warto dan (b) rumah Bapak Nugroho

Sumber: Hasil survei, 2014

Beberapa rumah warga sudah dibangun dan dikembangkan untuk memenuhi kebutuhan akomodasi wisatawan. Gambaran kondisi homestay di desa Pentingsari dapat dilihat pada gambar 5. Berdasarkan pengamatan lapangan terlihat bahwa kondisi homestay di desa Pentingsari sudah cukup baik, hal ini terlihat dari adanya pengembangan yang dilakukan oleh warga selaku pemilik.

\section{Pembahasan}

\section{Bentuk Partisipasi Masyarakat} untuk mendukung aktivitas wisata

Bentuk partisipasi masyarakat yang paling dominan dapat dilihat dalam bentuk atraksi wisata homestay. Warga desa secara sukarela melakukan berbagai bentuk pengembangan untuk meningkatkan kualitas layanan homestay di desa Pentingsari.

Lokasi homestay yang terdapat di desa Pentingsari tersebar cukup merata, hal ini terlihat pada peta gambar 6 . Keterlibatan warga menjadi unsur yang penting mengingat dominasi letak homestay tidak sekedar mendekati objek atau atraksi wisata saja namun diatur sesuai prinsip pemerataan oleh pengelola desa wisata. Hal ini dilakukan untuk menghindari kecemburuan yang dapat timbul di kalangan warga desa.

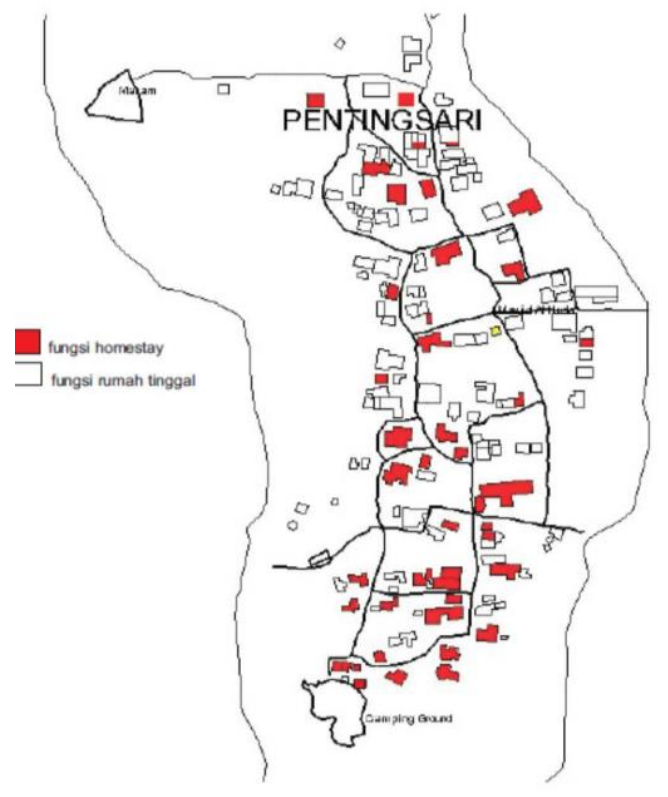

Gambar 6. Peta Sebaran homestay di desa Pentingsari

Sumber: Hasil survei, 2014 
Partisipasi pengembangan homestay

Saat ini desa Pentingsari memiliki 50 buah rumah warga yang aktif dijadikan homestay. Dengan kapasitas rata - rata 2 orang per kamar, secara keseluruhan homestay rumah warga dapat menampung maksimal 400 wisatawan menginap. Pemilihan sampel berdasarkan pada survey yang sudah dilakukan berdasarkan kriteria homestay (Vitasurya, 2012) yaitu :

1. Bersih

2. Sehat (sesuai standar rumah sehat)

3. Aman

4. Nyaman (sesuai standard kenyamanan bangunan dan tata letak perabot)

Berdasarkan hasil observasi lapangan dan wawancara secara terstruktur dengan warga masyarakat pemilik homestay, ditetapkan 8 (delapan) objek yang memenuhi criteria tersebut untuk diamati lebih lanjut. Dari pengamatan survey diperoleh hasil pada tabel 2 sebagai berikut.

Tabel 2. Identifikasi pengembangan homestay di desa Pentingsari

\begin{tabular}{cll}
\hline $\begin{array}{c}\text { Nazma } \\
\text { Pemilik }\end{array}$ & $\begin{array}{c}\text { Kapasitas } \\
\text { fasilitas }\end{array}$ & \multicolumn{1}{c}{$\begin{array}{c}\text { Identifikasi } \\
\text { pengembangan }\end{array}$} \\
\hline Ibu Ratno & 3 kamar & Alih fungsi ruang \\
& tidur, 2 & pada bangunan asli \\
& KM/WC, 1 & \\
\hline
\end{tabular}

Tabel 3.a

Identifikasi fisik homestay desa Pentingsari

\begin{tabular}{|c|c|c|}
\hline $\begin{array}{l}\text { Nazma } \\
\text { Pemilik }\end{array}$ & $\begin{array}{l}\text { Kapasitas } \\
\text { fasilitas }\end{array}$ & $\begin{array}{c}\text { Identifikasi } \\
\text { pengembangan }\end{array}$ \\
\hline & $\begin{array}{l}\text { ruang } \\
\text { pertemuan }\end{array}$ & \\
\hline Pak Nugroho & $\begin{array}{l}3 \text { kamar } \\
\text { tidur, } 1 \\
\text { KM/WC }\end{array}$ & $\begin{array}{l}\text { Penambahan } \\
\text { bangunan }\end{array}$ \\
\hline Pak Doto & $\begin{array}{l}1 \text { kamar } \\
\text { tidur, } 1 \\
\text { KM/WC dan } \\
1 \text { ruang } \\
\text { pertemuan } \\
\end{array}$ & $\begin{array}{l}\text { Penambahan } \\
\text { bangunan }\end{array}$ \\
\hline Ibu Joko & $\begin{array}{l}2 \text { kamar } \\
\text { tidur, } 1 \\
\text { KM/WC, } 1 \\
\text { ruang } \\
\text { pertemuan }\end{array}$ & $\begin{array}{l}\text { Alih fungsi ruangan } \\
\text { pada bangunan lama }\end{array}$ \\
\hline Pak Sakidjo & $\begin{array}{l}2 \text { kamar } \\
\text { tidur, } 3 \\
\text { KM/WC, } 1 \\
\text { ruang } \\
\text { pertemuan }\end{array}$ & $\begin{array}{l}\text { Alih fungsi ruangan } \\
\text { pada bangunan lama } \\
\text { dan tambahan } 1 \\
\text { bangunan baru untuk } \\
\text { KM/WC }\end{array}$ \\
\hline $\begin{array}{l}\text { Omahe } \\
\text { Simbok }\end{array}$ & $\begin{array}{l}1 \text { kamar } \\
\text { tidur, } 1 \\
\text { KM/WC, } 1 \\
\text { ruang tamu }\end{array}$ & $\begin{array}{l}\text { Bangunan baru yang } \\
\text { khusus difungsikan } \\
\text { untuk homestay }\end{array}$ \\
\hline Pak Kris & $\begin{array}{l}1 \text { kamar } \\
\text { tidur, } 2 \\
\text { KM/WC }\end{array}$ & $\begin{array}{l}\text { Penambahan lantai } \\
\text { atas bangunan lama }\end{array}$ \\
\hline $\begin{array}{l}\text { Pak } \\
\text { Ngadiran }\end{array}$ & $\begin{array}{l}3 \text { kamar } \\
\text { tidur, } 1 \\
\text { KM/WC, } 1 \\
\text { ruang } \\
\text { pertemuan }\end{array}$ & $\begin{array}{l}\text { Alih fungsi ruangan } \\
\text { pada bangunan lama }\end{array}$ \\
\hline
\end{tabular}

Sumber: Hasil survei, 2014

Dari identifikasi secara umum, kami memperjelas identifikasi terhadap 5 sampel model homestay yang terdapat di desa Pentingsari secara khusus, berdasarkan jenis pengembangan. Penjelasan tersebut dijabarkan pada table 3 (a,b,c,d,e) berikut:

Diskripsi skematik

Penjelasan

Homestay Ibu Ratno

Tata Letak

- Menyatu

- Alih fungsi ruang

- Akses bersama

- Luas area homestay : $18.5 \mathrm{~m}$ x $6.25 \mathrm{~m}=115.625 \mathrm{~m} 2$,

- Luas bangunan keseluruhan $219.625 \mathrm{~m} 2$

- Menggunakan $50 \%$ dari keseluruhan bangunan.

\section{Kualitas Ruang}

Area duduk menyatu dengan ruang keluarga. Ruang duduk adalah pusat dari rumah induk dan memiliki akses yang utama, hal ini memungkinkan wisatawan berinteraksi langsung dengan pemilik rumah maupun wisatawan lain.

Fasilitas ruang: Pengecatan kembali.kamar eksisting. 


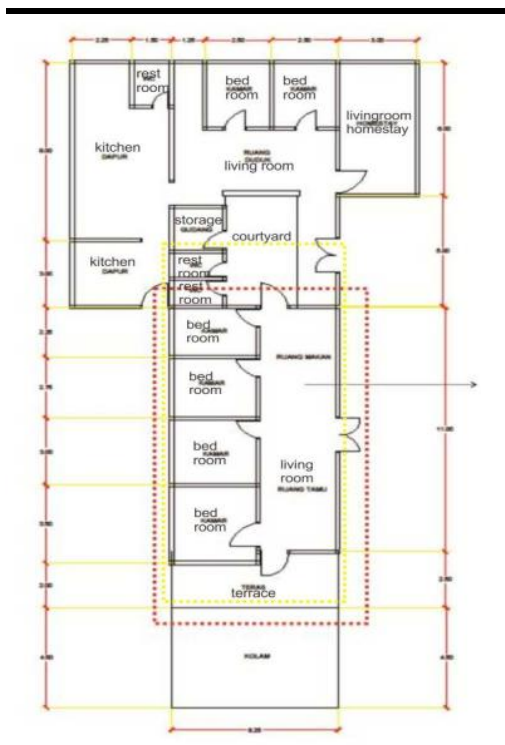

Pengudaraan alami diperbaiki dengan memperlebar jendala, sekaligus untuk pencahayaan alami. Kamar untuk 2 orang dilengkapi lemari. Kamar mandi di belakang dan memenuhi standard sanitasi yang baik

expansion area homestay area
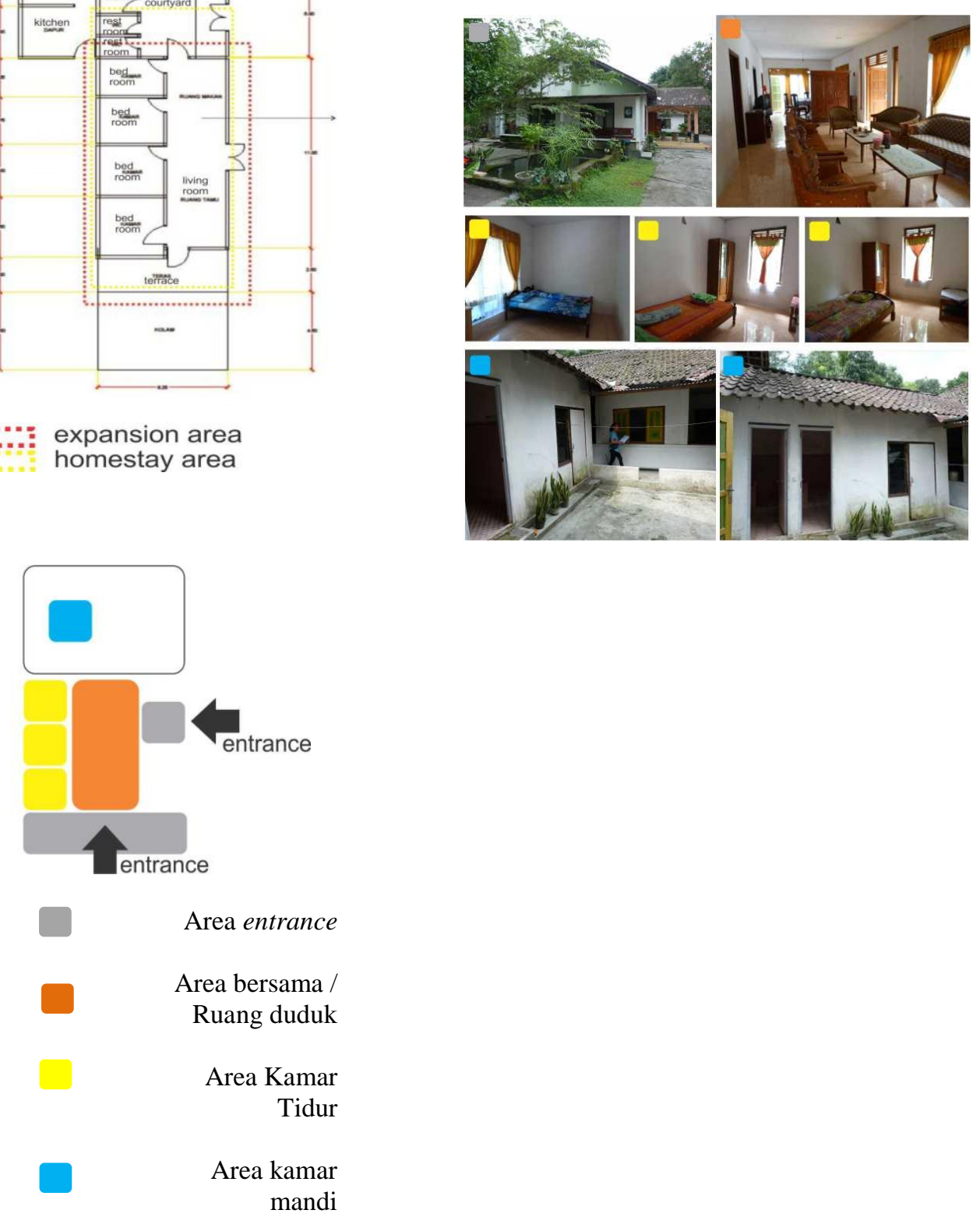

Sumber: Hasil survei, 2014 
Tabel 3.b

Identifikasi fisik homestay desa Pentingsari

Deskripsi skematik

Homestay Bapak Nugroho

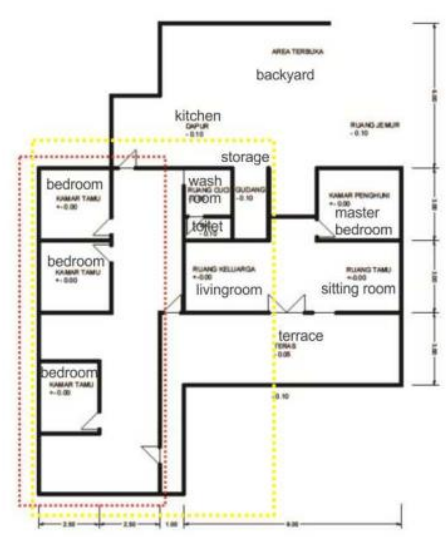

....: expansion area

homestay area

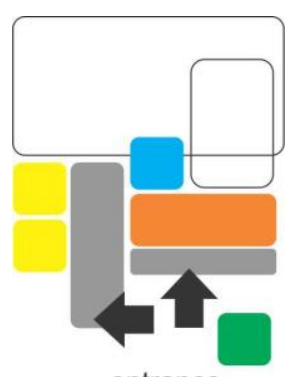

entrance

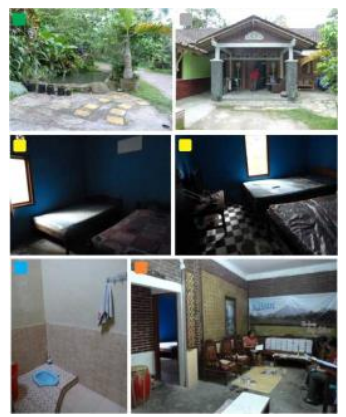

Area entrance

Area bersama /

Ruang duduk

Area Kamar

Tidur

Area kamar

Mandi

Taman
Penjelasan

\section{Tata Letak}

- Menyatu

- Akses homestay terpisah namun berdekatan dengan akses utama

- Luas area homestay :

$5 \mathrm{~m} \times 12 \mathrm{~m}=60 \mathrm{~m} 2$.

- Luas bangunan $=135 \mathrm{~m} 2$

- Menggunakan 50\% dari keseluruhan luas bangunan.

Kualitas Ruang

Akses utama terhubung dengan akses homestay. Teras dirancang dengan elemen alami untuk menciptakan suasana tradisional.

Ruang keluarga berada di tengah bangunan dan menjadi pusat aktivitas. Elemen dekorasi tradisional ditambahkan untuk menciptakan suasana tradisional dan menjadi cirikhas homestay ini. Ruang tidur berada pada bagian tambahan bangunan, Pengkondisian udara dan cahaya alami yang baik.

Fasilitas Ruang tersedia untuk 2 orang yang dilengkapi dengan lemari

Kamar mandi berada di belakang dengan kualitas bangunan yang baik dan memenuhi standard sanitasi. Homestay ini juga memiliki taman dan kolam hias sehingga dapat menjadi nilai tambah. 
Tabel 3.c.

Identifikasi fisik homestay desa Pentingsari

Deskripsi skematik

Homestay Bapak Doto

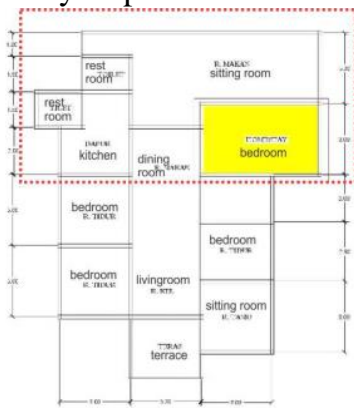

c. homestaY Pak doto

expansion area

homestay area
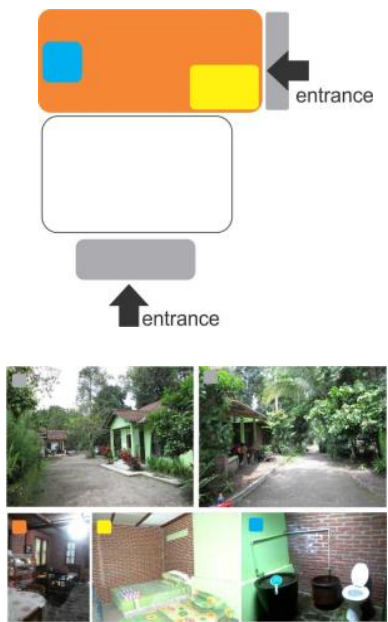

Area entrance

Area bersama /

Ruang duduk

Area Kamar

Tidur

Area kamar

mandi
Penjelasan

Tata Letak

- Menyatu

- Akses homestay terpisah.

- Luas area homestay:

$6 \mathrm{~m} \times 12 \mathrm{~m}=72 \mathrm{~m} 2$,

- Luas bangunan $=81 \mathrm{~m} 2$

- Menggunakan $80 \%$ dari keseluruhan luas bangunan

Kualitas Ruang

Homestay memiliki akses tersendiri.

Penambahan elemen dekorasi menarik wisatawan sekaligus memberikan privacy. Ruang tidur berada di area penambahan. Pengkondisian udara dan pencahayaan sudah memenuhi syarat.

Fasilitas ruang tidur untuk 2 orang dilengkapi dengan nakas dan lemari. Ruang duduk untuk wisatawan berada di bagian belakang area penambahan. Elemen dekorasi tradisional ditambahkan untuk menciptakan suasana tradisional. Kamar mandi berada di tengah bangunan di bagian timur. Kamar mandi sudah memenuhi standard sanitasi yang baik.

Sumber: Hasil survei, 2014 


\section{Tabel 3.d}

\section{Identifikasi fisik homestay desa Pentingsari}

Deskripsi skematik

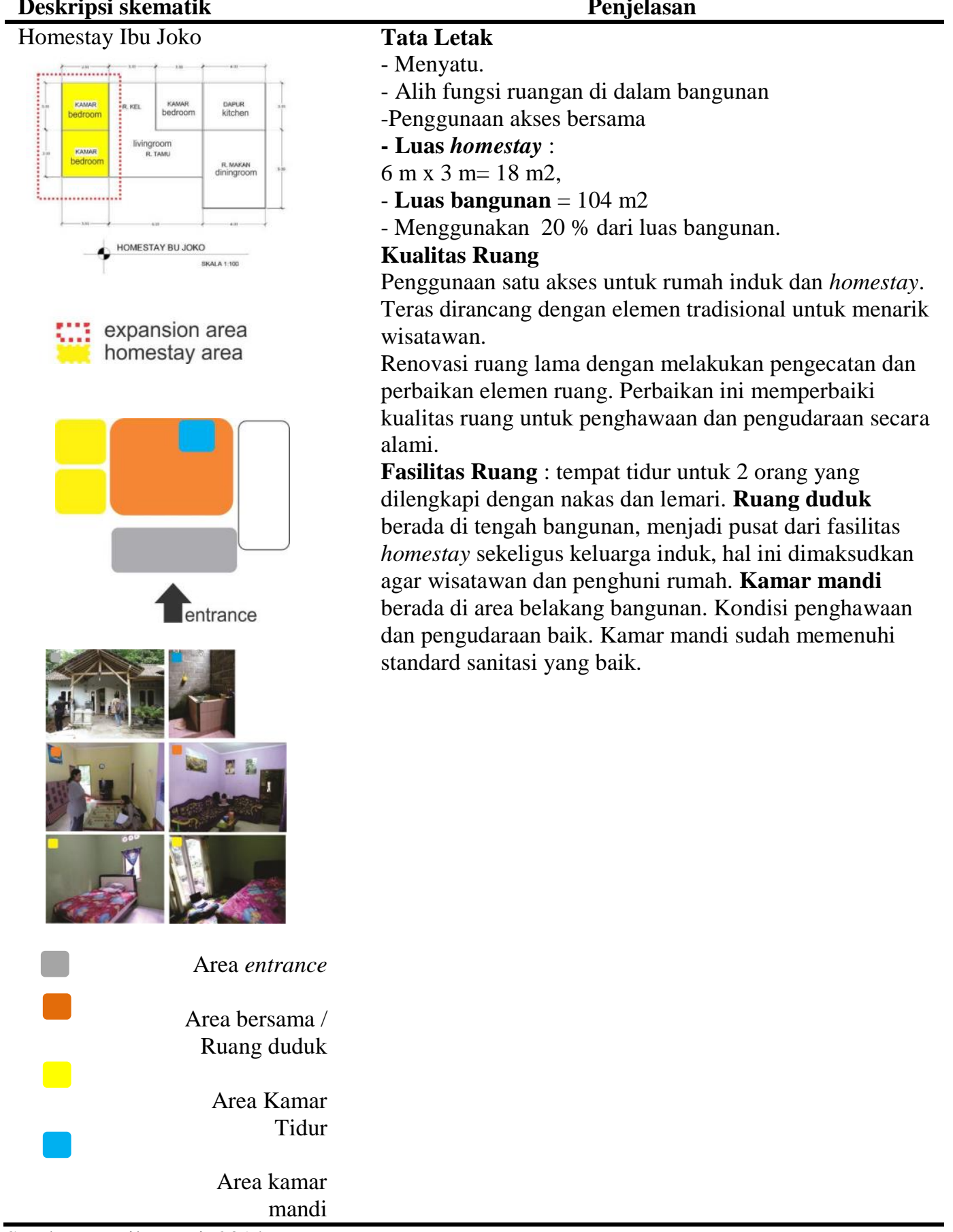

Sumber: Hasil survei, 2014 
Tabel 3.e

Identifikasi fisik homestay desa Pentingsari

Deskripsi skematik

Penjelasan

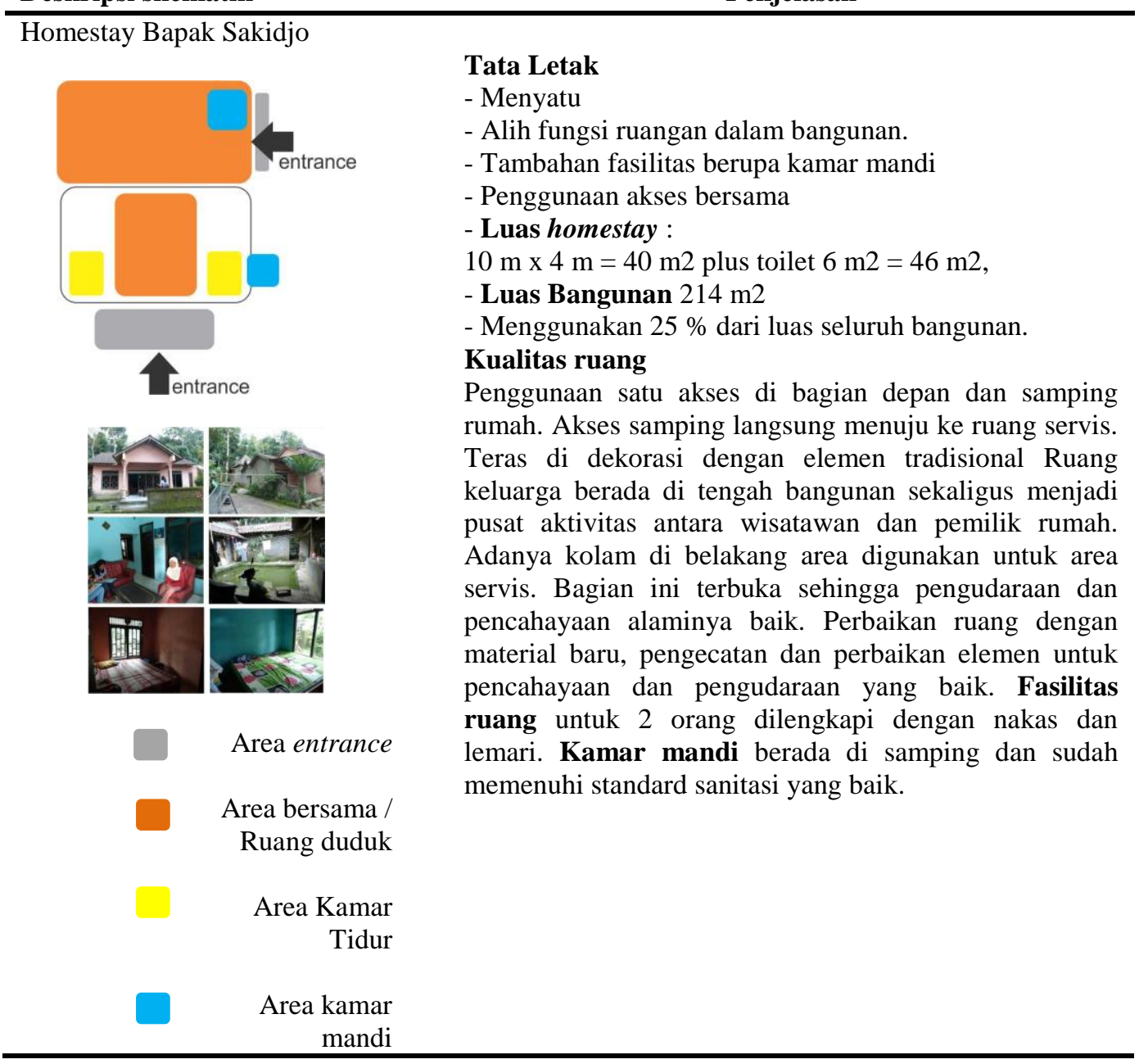

Sumber: Hasil survei, 2014

Dari identifikasi diatas, dapat dijabarkan beberapa hasil yaitu :

a) Tatanan ruang yang dikembangkan menjadi fasilitas homestay tidak mengubah bangunan asli rumah penduduk.

Hal ini terlihat pada contoh homestay Ibu Warto pada gambar 7 berikut.

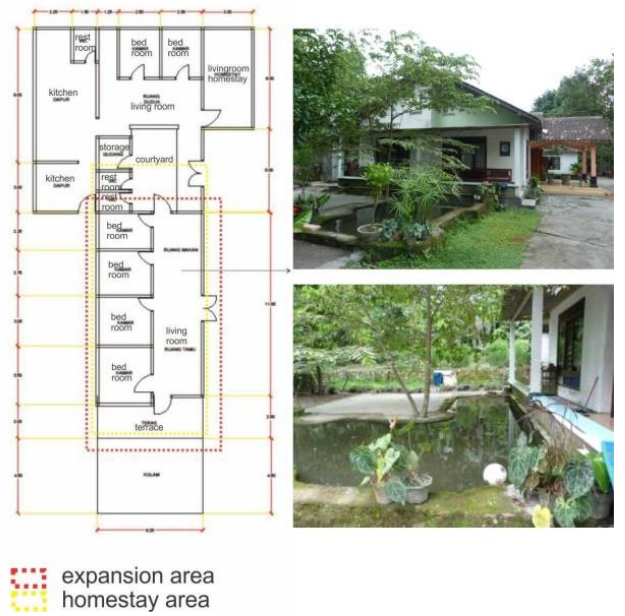

Gambar 7. Tata letak asli bangunan rumah tidak diubah hanya mengganti fungsi dan memperbaiki kualitas ruang.

Sumber: Analisis. 2014 
b) Fasilitas yang dikembangkan menjadi fasilitas homestay (kamar inap, ruang bersama dan kamar mandi) menggunakan ruangan pada bangunan lama yang direnovasi sehingga memenuhi standard kebersihan dan kenyamanan bagi tamu. Hal ini terlihat pada gambar 8 berikut.
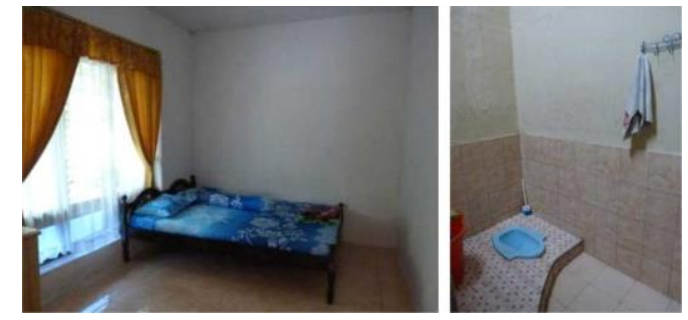

Gambar 8. Contoh renovasi ruang untuk memperbaiki kualitas ruang

Sumber : Hasil survei, 2014

c) Penambahan bangunan tidak banyak dilakukan. Sebagian besar hanya dilakukan pada fasade bangunan untuk menampilkan identitas rumah yang lebih nyaman seperti pada gambar 9 .
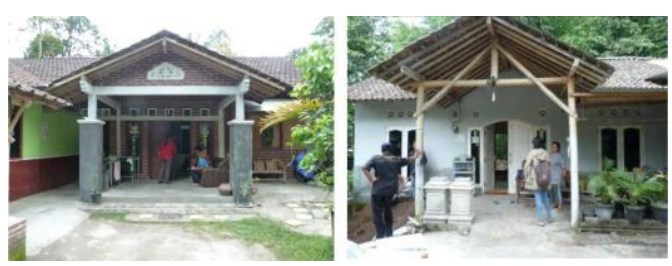

Gambar 9. Perbaikan fasade untuk menambah daya tarik tampilan rumah / homestay.

Sumber: Hasil survei, 2014

d) Penggunaan ruang bersama antara penghuni rumah dan tamu menjadi daya tarik utama, karena tamu tidak merasa terpisah dan dapat berinteraksi langsung seperti pada gambar 10.
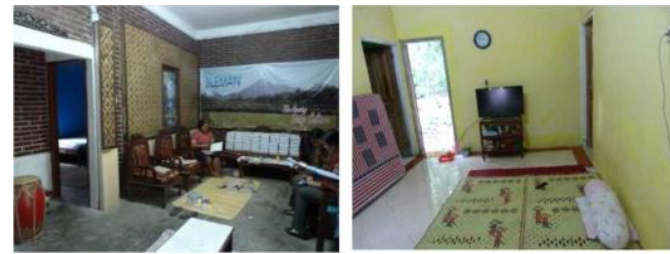

Gambar 10. Penggunaan ruang bersama tamu dan penghuni rumah menjadi daya tarik khusus atraksi wisata homestay.

Sumber: Hasil analisis, 2014

e) Pengembangan dilakukan sesuai dengan kondisi rumah masing masing warga, sehingga tidak ada standard yang baku untuk luasan dan kualitas bangunan yang harus disediakan. Standard yang ditetapkan lebih pada skala kebersihan dan kesehatan.

f) Warga melakukan penambahan dan pengembangan sesuai dengan kemampuan masing - masing secara keuangan dan ketersediaan lahan yang dimiliki.

\section{Kesimpulan}

Bentuk partisipasi masyarakat desa Pentingsari untuk mendukung aktivitas wisata berupa penggunaan rumah tinggal penduduk sebagai bagian dari fasilitas homestay (ruang inap) bagi wisatawan. Warga desa melakukan hal ini secara sukarela sesuai dengan kemampuan dan kondisi masing masing namun tetap dalam standard layak huni.

Bentuk pengembangan rumah tinggal penduduk dalam upaya mengembangkan fasilitas homestay dapat dibagi menjadi :

a) Pengembangan berupa alih fungsi ruang pada rumah atau bangunan lama yang sudah tidak dipergunakan untuk dirubah menjadi kamar inap wisatawan

b) Pengembangan berupa penambahan bagian bangunan yang masih menyatu dengan rumah utama 
(vertical dan horizontal) menjadi kamar inap dan fasilitas pendukung homestay seperti kamar mandi dan ruang pertemuan

\section{Penghargaan}

Penghargaan ditujukan pada seluruh anggota tim riset HIBAH Bersaing PUSWIRA Universitas Atma Jaya Yogyakarta atas kesempatan yang diberikan untuk melakukan riset "Model Pemberdayaan desa Wisata berbasis pelestarian lingkungan berkelanjutan dalam upaya peningkatan kesejahteraan masyarakat di DIY, tahun 2014". Riset ini sepenuhnya didanai oleh DIKTI (Dinas Pendidikan Tinggi Republik Indonesia) tahun anggaran 2014, dan masih dijalankan hingga Desember 2014. Penelitian ini diharapkan menjadi bagian dari model pemberdayaan masyarakat melalui potensi desa wisata yang berdasarkan pada kelestarian lingkungan.

Hal ini ditujukan agar proses pemberdayaan tersebut tetap sejalan dengan prinsip berkelanjutan terutama dari sisi lingkungan.

\section{Daftar Pustaka}

Dinas Kebudayaan dan Pariwisata, Kabupaten Sleman (2012). Profil Desa Wisata di Kabupaten Sleman.

Fandeli, C. (2000). Pengusahaan ekowisata. Yogyakarta: Penerbit Fakultas Kehutanan Universitas Gadjah Mada.

Herawati, et al (2014). Rural tourism community empowerment based on local resources for improving community welfare. RIBER Jurnal vol 3(2).

Mikkelsen, B. (2001). Metode penelitian partisipatoris dan upaya-upaya pemberdayaan: Sebuah buku pegangan bagi para praktisi lapangan. Edisi 2. Jakarta: Yayasan Obor Indonesia (terjemahan).

Pudianti, A. (2013). Budaya sebagai dasar konsep lingkungan berkelanjutan pada Desa Wisata Pentingsari, Sleman, DIY. (Makalah seminar proposal disertasi S3 Arsitektur UNDIP, 2013. Tidak dipublikasikan).

Purwaningsih, et al. (2014). Model pemberdayaan desa wisata berbasis pelestarian lingkungan berkelanjutan dalam upaya peningkatan kesejahteraan masyarakat di DIY. (Proposal Riset Penelitian Hibah Bersaing Dikti 2014 oleh tim PUSWIRA. Tidak Dipublikasikan)

Royo-Vela, M. (2009). Rural-cultural excurtion conseptualization: A local tourism marketing management model based on tourist destination image measurement. Journal Tourism Management 30 (2009) hal. 419-428. Journal online Elsevier.

Tim Puswira (2011). Pendampingan masyarakat Desa Gilangharjo menuju Desa Wisata yang ramah lingkungan (Gilangharjo green entrepreneurship's rural tourism). (Laporan Pengabdian Universitas Atma Jaya Yogyakarta. Tidak dipublikasikan).

Tim Puswira (2012). Pendampingan masyarakat dalam pengembangan Desa Wisata Gilangharjo. (Laporan Pengabdian Universitas Atma Jaya Yogyakarta. Tidak dipublikasikan). 
Tim Penyusun Kamus Pembinaan dan Pengembangan Bahasa (1997). Kamus Besar Bahasa Indonesia Edisi Kedua. Jakarta: Balai Pustaka

Vitasurya, V. R. (2012). Adaptive Space sebagai alternatif pengembangan homestay di desa wisata. Studi kasus Desa Wisata Gilangharjo Bantul Yogyakarta. Prosiding Seminar Nasional SCAN 3 Stick and Carrot, Prodi Arsitektur UAJY. 